\title{
O METODOLOGII ARCHIWISTYKI I TEORII ARCHIWALNEJ. PRZEGLĄD OGÓLNY PIĘĆDZIESIĘCIOLETNICH BADAŃ
}

\author{
Słowa kluczowe \\ teoria archiwalna, metodologia archiwistyki, komputeryzacja archiwów
}

\section{Keywords}

archival theory, archive studies methodology, archives computerization

\section{Streszczenie}

Autor w uporządkowanym, a w kilku aspektach także osobistym wywodzie, zaprezentował przegląd swojego metodologicznego i teoretycznego dorobku naukowego, w swoim opisie nie unika też pewnych podsumowań i ocen własnego dorobku, także z perspek-

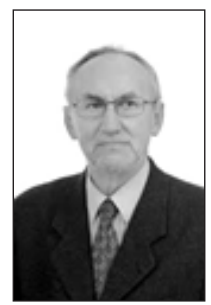

Bohdan Ryszewski, profesor, zajmuje się teoretycznymi podstawami archiwistyki jako nauki, jej metodami badawczymi, problemami informacji naukowej. Publikował liczne prace naukowe z zakresu archiwistyki, jest twórcą polskiego modelu opisu archiwalnego FOPAR. Od 1966 do 1998 r. wykładał na specjalizacji archiwalnej Uniwersytetu Mikołaja Kopernika w Toruniu. W 1998 r. założył specjalizację archiwalną na Uniwersytecie Warmińsko-Mazurskim w Olsztynie i prowadził tam wykłady i seminaria do 2008 r. Od 1986 r. prowadził seminarium doktoranckie na UMK i UW-M. Przewodniczy zespołowi naukowemu „Symposia Archivistica”, który organizuje corocznie sympozja i publikuje ich materiały. 
tywy krytycznej. Skupił się zwłaszcza na opisaniu powstawania trzech rozpraw monograficznych, które opublikował w latach 1972-1994: Archiwistyka - przedmiot, zakres, podział (studia nad problemem) z 1972 r.; Problemy i metody badawcze archiwistyki z 1985 r.; Problemy komputeryzacji archiwów z 1994 r.

\section{Summary}

About methodology of archive studies and archival theory.

General overview of a fifty-year research

In an orderly and, in many cases, personal argument the Author presents an overview of his methodological and theoretic achievements, not avoiding summaries and evaluations, also those from a critical perspective. In particular, the Author focuses on writing three monographs published between 1972 and 1994: Archiwistyka. Przedmiot, zakres, podział (studia nad problemem) from 1972, Problemy i metody badawcze archiwistyki from 1985 and Problemy komputeryzacji archiwów from 1994.

1B) adaniu problemów metodologii archiwistyki i teorii archiwalnej poświęciłem prawie całe swoje aktywne życie, bowiem zacząłem się nimi zajmować w 1966 r. i mogę dalej prowadzić badania, oczywiście coraz bardziej wspierany przez moich uczniów. Moje wystąpienie nie będzie jednak pełnym omówieniem zapowiadanej problematyki, a raczej relacją z własnych badań i komentarzem do ich wyników.

Mam nadzieję, że będzie to miało pewną wartość, obejmuje bowiem pięćdziesiąt lat badań powiązanych z półwiecznym okresem nauczania uniwersyteckiego. Udało mi się połączyć nauczanie z badaniami, przy czym edukowanie było dla mnie zawsze inspiracją dla podejmowanych badań. Dlatego mam uczniów kontynuujących badania zarówno w zakresie problematyki, którą się zajmowałem, jak i metodologii. Oczywiście nie śmiałbym zajmować uwagi Państwa swoimi badaniami, gdyby nie to, że ostatnio budzą one większe zainteresowanie.

Jestem jednym z niewielu badaczy i nauczycieli akademickich zajmujących się wyłącznie archiwistyką i to w pełnym zakresie, bo nie tylko teorią archiwalną i metodyką, nie tylko archiwoznawstwem, ale także tym, co archiwistyka sądzi sama o sobie - metodologią archiwistyki. Nie ulegałem pokusie zajmowania się tematami historycznymi.

Początkowo zamierzałem nadać swemu wystąpieniu układ rzeczowy, ale kiedy przypominałem sobie rezultaty moich badań z zakresu metodologii archiwistyki i teorii archiwalnej, zaczęły one układać się w pewnej chronologii. Wielka bowiem jest zależność naszej pracy i jej efektów od zmieniających się warunków. 
Przede wszystkim doszedłem do wniosku, że jakiekolwiek rezultaty moich badań zależą od tego etapu w moim życiu, który nazwać trzeba okresem zawodowym. Jest to czas niemały, bo dziesięć lat. Zaczął się od studiów na tak zwanym Studium Archiwalnym podjętym na III roku kierunku historia na Uniwersytecie Mikołaja Kopernika w Toruniu w 1956 r. Odbywałem te studia pod kierunkiem Franciszka Paprockiego, archiwisty o ogromnym doświadczeniu i gruntownej wiedzy archiwalnej. Był on, o czym się już nie pamięta, nauczycielem zawodu archiwisty wielu pokoleń archiwistów nie tylko na studiach, ale także na kursach zawodowych. Zajęcia były wzbogacane przez wykłady z historii ustroju i seminaria profesora Wojciecha Hejnosza, który miał też za sobą długą praktykę archiwalną pod kierunkiem Oswalda Balzera w Archiwum Aktów Grodzkich i Ziemskich we Lwowie. Przedmioty te - archiwistyka i historia ustroju - uzupełniały ćwiczenia z paleografii i neografii łacińskiej, niemieckiej, ruskiej i rosyjskiej, także prowadzone przez znakomitych specjalistów. Podstawę studiów stanowiły normalne studia historyczne. Wysoko oceniam po wielu latach doświadczeń, także w kształceniu archiwistów, program i poziom ówczesnych studiów archiwalnych, w szczególności rozległą wiedzę a także doświadczenie zawodowe wykładowców podstawowych przedmiotów. Dostrzegam też obecnie zalety dawnego programu wynikające ze skupienia wiedzy archiwistycznej w jednym przedmiocie, w szczególności połączenie wiedzy aktoznawczej z metodyką archiwalną.

Zetknąłem się też wówczas na ćwiczeniach z archiwistyki prowadzonych przez Franciszka Paprockiego z dziełem Adolfa Brennekego pt. Archivkunde ${ }^{1}$, które wówczas było nowością, wydane w Lipsku w 1953 r. Dzieło to, teraz już niedoceniane może ze względu na trudny język, odegrało dużą rolę w moich studiach metodologicznych i teoretycznych. Należę do niewielkiego grona zwolenników wolnej zasady proweniencji Brennekego jako podstawy jednej $\mathrm{z}$ metod porządkowania.

Studia na toruńskim Studium Archiwalnym dały mi dobre podstawy do samodzielnej pracy w Archiwum Państwowym w Kielcach, było to bowiem wówczas archiwum o nielicznej kadrze archiwistów o różnym wykształceniu, a uniwersyteckie przygotowanie do pracy w archiwum wyraźnie wyróżniało zatrudnionych wówczas w 1958 roku dwoje młodych adeptów (obok mnie nieco później zatrudniona była Teresa Koba-Ryszewska). Był jednak w zespole archiwistów województwa kieleckiego znakomity specjalista z archiwum w Ra-

${ }^{1}$ A. Brenneke, Archivkunde. Ein Beitrag zur Theorie und Geschichte des europäischen Archivwesens, , wyd. W. Leesch, Leipzig 1953, ss. 542. 
domiu Władysław Prawdzik, który zadziwiał nas swoją gruntowną wiedzą, także teoretyczną, zdobytą w czasie szkoleń przedwojennych i wspierał w trudnych dyskusjach na zebraniach naukowych. Nieliczny personel archiwum kieleckiego zmuszał do wykonywania wszystkich funkcji archiwum państwowego i opracowywania różnych zespołów archiwalnych. Rozszerzało to moje doświadczenie.

Duży wpływ na moje zainteresowania naukowe archiwistyką wywarła piąta archiwalna konferencja metodyczna w grudniu 1961 r., na której widziałem i słyszałem przedstawicieli odchodzącego pokolenia archiwistów przedwojennych, jeszcze wówczas bardzo aktywnych: Kazimierza Konarskiego i Piotra Bańkowskiego, Kazimierza Arłamowskiego, Mariana Friedberga, Adama Stebelskiego. W tej właśnie konferencji metodycznej rozważano na podstawie referatu Kazimierza Arłamowskiego problemy archiwistyki jako nauki, przy czym dominował pogląd, że jej zakres winien odpowiadać naukowym potrzebom archiwistyki. Drugim problemem teoretycznym było zagadnienie zespołu archiwalnego i zasady proweniencji dyskutowane na podstawie referatu Adama Stebelskiego. Natomiast Kazimierz Konarski, czynny zawodowo mimo lat siedemdziesięciu pięciu, omawiał problemy indeksowania i sumaryzowania akt. Interesująca i niekiedy burzliwa była dyskusja nad poszczególnymi referatami. Konferencja ta miała wyraźnie naukowy charakter. Mimo trudnych warunków życie naukowe archiwów było na wysokim poziomie, przede wszystkim dzięki aktywności najstarszego pokolenia i jego dobrym stosunkom z Naczelnym Dyrektorem Archiwów Państwowych Henrykiem Altmanem, który po nominacji szybko uzyskał dobrą orientację w działalności archiwów.

Jakie znaczenie miały wykształcenie specjalistyczne i doświadczenie zawodowe dla późniejszej mojej kariery naukowej? Otóż specjalistyczne wykształcenie archiwistyczne w ogóle umożliwiło mi zrozumienie literatury naukowej z zakresu tej dyscypliny. Pobudziło zainteresowania i przekonanie o naukowym charakterze pracy archiwalnej, o którym do obecnej chwili jestem przekonany. Doświadczenie zawodowe - dzięki temu, że miałem dużą samodzielność merytoryczną - służyło mi zawsze do weryfikacji ustaleń teoretycznych, umacniało przekonanie o słuszności i celowości badań. Miało to tym większą wartość, że zawsze potem pracowałem bez wsparcia otoczenia, które składało się z historyków niemających większego zrozumienia dla naukowych aspiracji archiwistyki i archiwistów.

W 1965 r. otrzymałem propozycję pracy w Katedrze Archiwistyki i Nauk Pomocniczych Uniwersytetu Mikołaja Kopernika w Toruniu i propozycję przyjąłem mimo bardzo trudnych warunków. Przez przeszło trzy lata dojeżdżałem do pracy z Kielc do Torunia. Zatrudniono mnie jako doświadczonego archiwi- 
stę, mającego w dorobku parę publikacji, dobrą opinię z uniwersytetu i pracy zawodowej. Miałem prowadzić ćwiczenia z archiwistyki, okazało się jednak, że dotychczasowy wykładowca archiwistyki docent Franciszek Paprocki rezygnuje z wykładów i powierzono mi wszystkie zajęcia z archiwistyki na III roku studiów archiwalnych. Pierwszy semestr zajęć obejmował zagadnienia metodologiczne i teoretyczne archiwistyki: przedmiot, zakres i podział archiwistyki, rozwój archiwistyki, terminologię, jej zasady, procesy archiwotwórcze. Zakres tematyczny tego programu odpowiada w zasadzie mojemu dorobkowi. Tak więc autorzy programu studiów archiwalnych na UMK, wtedy jedynych na polskich uniwersytetach, dokładnie wyznaczyli zakres moich zainteresowań naukowych.

Studiowanie literatury do pierwszego wykładu uniwersyteckiego sprawiło, że tematem mojej rozprawy doktorskiej stał się tytuł tego wykładu: Archiwistyka - przedmiot, zakres, podziat. W czasie dyskusji nad koncepcją pracy na seminarium doktoranckim i zebraniu naukowym traktowano moje plany $\mathrm{z}$ rezerwą, a niekiedy byłem zniechęcany do tej pracy. Uważano ten temat za zbyt teoretyczny i tym samym trudny dla doktoranta. W swoich badaniach oparłem się nie tylko na dość gruntownej literaturze archiwalnej, ale także literaturze z metodologii ogólnej. Po trzech latach rozprawa została ukończona i przyjęta jeszcze przed obroną doktoratu do druku w Rocznikach Towarzystwa Naukowego $w$ Toruniu ${ }^{2}$. Jej wartość, moim zdaniem, polega na opracowaniu zarysu rozwoju archiwistyki do połowy XX w., przeprowadzeniu dowodu na odrębność archiwistyki jako dyscypliny naukowej, ustaleniu jej zakresu i granic problemowych oraz podziału dorobku. Ustalenia te zostały przyjęte w polskiej nauce. Dzisiaj książka ta jest mało dostępna, sam mam tylko jeden egzemplarz. Miałem propozycję wznowienia, ale pod warunkiem uzupełnienia treści o okres nowszy, które to działania nie wydały mi się uzasadnione. Ewentualne wznowienia po tak długim okresie są uzasadnione, ale treść książki, moim zdaniem, może być uzupełniona tylko $\mathrm{w}$ posłowiu.

W czasie oddawania do publikacji swojej rozprawy miałem już plan dalszej pracy - we wstępie już napisałem, że do podstawowych problemów metodologii archiwistyki należą także metody badawcze archiwistyki, które jednak ze względu na ograniczony stan badań jeszcze nie mogą zostać teraz, w momencie druku, omówione. Zdawałem sobie wówczas sprawę, że według wymagań metodologii ogólnej, metody badawcze archiwistyki powinny tworzyć zbiór dający możliwość badania wszystkich problemów archiwistyki. Wiedziałem

2 Zob. B. Ryszewski, Archiwistyka. Przedmiot, zakres, podziat (studia nad problemem), Warszawa-Poznań 1972. 
także, że archiwistyka może przejmować metody badawcze innych nauk. Nie wiedziałem jednak, że praca nad problemami metod badawczych zajmie mi tyle czasu - dopiero w 1978 r. byłem przygotowany naukowo do opracowywania następnej książki, której przygotowanie zajęło mi czas do $1982 \mathrm{r}$.

Przede wszystkim czas pracy nad nową książką wydłużył się z powodu objęcia stanowiska dyrektora Biblioteki Uniwersyteckiej w Toruniu, nieoczekiwanie jednak okazało się, że miało to pozytywny wpływ na zakres studiów.

Od 1975 r. zacząłem studia w zakresie nauk systemowych i informacyjnych, związane z zainteresowaniem możliwościami komputeryzacji bibliotek. Zdobyta wówczas wiedza okazała się pożyteczna, kiedy podjąłem bezpośrednią pracę nad rozprawą habilitacyjną w 1978 r. Jej plan nie przewidywał jednak tak szerokiej treści z zakresu nauk systemowych, w szczególności o systemach informacyjnych. Koncepcja rozprawy nawiązywała do wybitnej książki Witolda Kuli Problemy i metody historii gospodarczej. W trakcie pracy w powstającej rozprawie przeważać zaczęły rozważania o archiwalnych systemach informacyjnych i procesach archiwotwórczych, które później stały się teoretyczną podstawą studiów nad problemami komputeryzacji archiwów i nawet doprowadziły do sformułowania zasady strukturalnej. W 1982 r. rozprawa pt. Problemy i metody badawcze archiwistyki została oddana recenzentom - profesorom znanym z życzliwej postawy dla innowacji. Spotkała się jednak z ich nieufnością. Otrzymałem szereg postulatów dotyczących kwestii w rozprawie drugorzędnych, które wprowadziłem, chociaż dla zasadniczych celów rozprawy prawie nic nie znaczyły. Byłem też ostrzegany, zapewne przez życzliwość, przed trudnościami, jakie rodzą studia metodologiczne. Recenzje były jednak dobre, umożliwiły habilitację w 1984 r. i publikację rozprawy w 1985 r. $^{3}$. Książka stała się nieodzowną w prowadzeniu od 1986 r. seminarium doktoranckiego i kształceniu niemałego grona moich uczniów. Z naszego seminarium doktoranckiego wyszło 19 doktorów archiwistyki i bibliologii, a sześciu z nich uzyskało habilitację z zakresu archiwistyki lub bibliologii, uzyskując kwalifikacje profesorskie.

Zasadniczym celem rozprawy było oczywiście ustalenie zbioru metod badawczych archiwistyki. Na opisany w rozprawie zbiór złożyły się metody dotąd z powodzeniem stosowane, przede wszystkim metoda historyczna, a ponadto metody przejęte z innych nauk: metoda systemów (analiza systemowa), metody badania systemów informacyjnych. Udało się zatem w istotny sposób powiększyć zbiór metod badawczych archiwistyki odpowiednio do powiększenia jej

${ }^{3}$ Zob. tenże, Problemy i metody badawcze archiwistyki, Toruń 1985. 
zasobu. Osobne miejsce zajęło opisanie archiwalnych systemów informacyjnych. Problematyka badania archiwalnych systemów informacyjnych powiększyła zakres archiwistyki, stając się podstawą teoretyczną badania komputeryzacji archiwów. Ważne miejsce w rozprawie zajęło omówienie metody badania procesów archiwotwórczych poprzedzone zdefiniowaniem tych procesów. Procesy archiwotwórcze jako pojęcie znane było wcześniej, stanowiły też temat jednego z pierwszych moich wykładów uniwersyteckich. Dostrzegłem jednak ich początek w podręczniku holenderskim z $1898 \mathrm{r}^{4}$, natomiast opisana w rozprawie metoda ich badań stała się podstawą owocnego badania wielu archiwów i zespołów archiwalnych podejmowanych przez moich uczniów.

Dotychczasowy dorobek naukowy z zakresu metodologii archiwistyki, który mogę sobie przypisać, dotyczy metodologii pragmatycznej. Można to określić następującym tytułem: Archiwistyka jako nauka i jej metody badawcze. Pozostawiłem do dalszego badania apragmatyczną metodologię archiwistyki, którą dokładniej i prościej można określić jako metodologiczną ocenę dorobku archiwistyki - zbadanie jakości i kompletności zbioru twierdzeń i pojęć archiwistyki. W omawianej książce, w jej rozdziale siódmym napisałem zarys tego ujęcia, które można nazwać metodologią apragmatyczną archiwistyki. Nie wiem, czy jeszcze powstanie na ten temat książka. Obawiam się, że moje twórcze lata minęły. Zajmuje mnie raczej interpretacja dotychczasowych ustaleń. Lata, które mogłem na metodologię apragmatyczną archiwistyki poświęcić, zajęły badania problemów komputeryzacji archiwów i wynikających z nich zasad teoretycznych.

Tymczasem w 1985 r. w podręczniku Archiwistyka ${ }^{5}$, przygotowywanym na zlecenie PWN, podjąłem napisanie części obejmującej teorię i metodykę archiwalną. Całość podręcznika znacznie przekroczyła jednak ograniczoną przez wydawcę objętość, zmuszony byłem zatem, jako odpowiedzialny za przygotowanie całości, ograniczyć do minimum część własną - metodologię i teorię. Zarys tej problematyki zawiera mój referat przedstawiony na V Powszechnym Zjeździe Archiwistów w Olsztynie w 2007 r. pt. Teoretyczne podstawy działalności archiwów ${ }^{6}$. Być może uda się jeszcze skończyć i opublikować szerszą wersję tego opracowania.

4 S. Muller, J.A. Feith, R. Fruin, Hendleiding voor het Ordenen en Beschrijven van Archieven, ontworpen in opdracht van de Vereeniging van Archivarissen in Nederland, Groningen 1898.

${ }^{5}$ H. Robótka, B. Ryszewski, A. Tomczak, Archiwistyka, Warszawa 1989.

${ }^{6}$ Zob. B. Ryszewski, Teoretyczne podstawy działalności archiwów, [w:] Archiwa w nowoczesnym społeczeństwie. Pamiętnik V Powszechnego Zjazdu Archiwistów Polskich, Olsztyn 6-8 września 2007 r., red. J. Porazinski, K. Stryjkowski, Warszawa 2008, s. 15-22. 
Przełom w moich studiach nad komputeryzacją archiwów spowodowała rewolucja mikrokomputerowa, która umożliwiła bezpośrednią pracę na komputerach bez uciążliwych i powodujących pomyłki etapów pośrednich. W 1987 r. otrzymałem z środków na badania pierwszy mikrokomputer IBM z dyskiem o pojemności zaledwie $20 \mathrm{MB}$. Rozpocząłem pracę przy zastosowaniu programu ISIS, polegającą na tworzeniu baz danych do opisu archiwaliów. Takich baz danych sam założyłem dziesięć. Była to doświadczalna część mojej pracy. Opisałem to dość szczegółowo w wydanej w 1994 r. książce pt. Problemy komputeryzacji archiwów ${ }^{7}$.

Stanąłem na stanowisku tradycyjnym w archiwistyce, że dostęp do zawartości zasobu archiwalnego powinien odbywać się przez opis poszczególnych całości i części zasobu, uznałem bowiem jako zawodny bezpośredni dostęp do skanowanych archiwaliów. Kwestia ta była rozważana w niektórych referatach sympozjum Standaryzacja archiwalnego opisu archiwalnego, które odbyło się w Olsztynie w październiku 2015 r., a materiały zostały opublikowane w tomie III serii „Symposia Archivistica” w roku $2016^{8}$.

Rezultatem tych studiów na bazach danych oraz literatury naukowej, głównie angielskiej - chodzi o znane prace Michaela Cooka i opisy standardów opisu archiwaliów - było sformułowanie zasady strukturalnej i opracowanie standardu FOPAR.

Zasada strukturalna zalecała jako obowiązującą analizę struktury zasobu archiwalnego, jej poszanowanie i rekonstrukcję. Rozszerzała zasadę proweniencji i mogła stać się podstawą znacznych zmian w obowiązującej metodyce. Jest to temat sam w sobie. Zastosowanie zasady strukturalnej uważam za nieodzowne w komputeryzacji archiwów drogą klasyczną, opisaną w książce Problemy komputeryzacji archiwów.

FOPAR w istocie jest niczym innym jak tylko tradycyjnym standardem opisu archiwalnego, w którym uwzględniono należycie wymagania informatologiczne i systemowe, stosuje się zalecenia zasady strukturalnej, a ponadto opis na każdym poziomie struktury zasobu uwzględnia należycie jego charakterystykę wyszukiwawczą.

W pracach nad komputeryzacją podjąłem w latach 1992-1998 próbę rozszerzenia badań nad komputeryzacją archiwów. W tym celu zorganizowałem siedem sympozjów. Dzięki grantom UMK i KBN na tym etapie, po ukończeniu moich prac teoretycznych i po opracowaniu standardu FOPAR, podjąłem nie

7 Tenże, Problemy komputeryzacji archiwów, Toruń 1994.

8 Standaryzacja opisu archiwalnego (seria Symposia archivistica, t. 3), red. J. Bednarek, P. Perzyna, Warszawa-Łódź 2016. 
zawsze udaną próbę wciągnięcia do pracy moich współpracowników, głównie przy referatach na sympozjach, którzy zajmowali się między innymi tzw. rozszerzeniem FOPAR-u. Dzięki posiadanym środkom współpracowało ze mną na różnych etapach pracy pięćdziesiąt osób - archiwistów, historyków i informatyków.

Mimo to efekt upowszechnienia FOPAR-u był połowiczny, choć powstał znaczny dorobek opublikowany w utworzonej wówczas serii wydawniczej Komputeryzacja archiwów. Standard FOPAR został nieufnie przyjęty w środowiskach archiwalnych, choć nie znam na jego temat żadnej otwartej krytyki, a jedynie pośrednio do mnie docierające opinie na temat nadmiernej szczegółowości opisów jednostkowych. Jest on w istocie mało znany. Nikt też nie pytał mnie o jego źródła, które tkwią - mogę to wskazać - w dorobku archiwistyki polskiej.

Okres od 1998 r. już nie przynosił nowych rezultatów w moich pracach metodologicznych i teoretycznych. Zainteresowanie moimi pracami osłabło, kontakty z NDAP ograniczyły się do zlecania mi recenzji tłumaczeń standardów i opinii. Działało jednak seminarium - magisterskie i doktoranckie, dzięki którym zyskałem bardzo zdolnych i rozwijających się współpracowników. Jubileusz dwudziestopięciolecia seminarium doktoranckiego dał sposobność do inicjatywy polegającej na wznowieniu zebrań naukowych w ulubionej przeze mnie formie kameralnych sympozjów. Już w 2012 r. zaczęliśmy organizować doroczne sympozja z dobranym gronem referentów i zamkniętym gronem uczestników. Od 2013 r. zajmujemy się problemami komputeryzacji archiwów. Materiały każdego sympozjum są publikowane - od drugiego sympozjum w osobnej serii „Symposia Archivistica”, którego tom pierwszy został opublikowany jako wydawnictwo IPN 9 .

Prace nasze poświęcone teorii archiwalnej trwają. W 2016 r. sympozjum poświęcono problemom opisu archiwalnego w skomputeryzowanych systemach informacyjnych i obecnie funkcjonujących bazach danych, na wszystkich poziomach opisu ${ }^{10}$.

Swoją ostatnią książkę dedykowałem moim uczniom, z którymi współpraca była dla mnie zawsze inspiracją. Teraz moi uczniowie przejęli trud dziłąń nad podjętą przeze mnie problematyką. Nadaje to sens mojej pracy.

9 Zasada strukturalna jako podstawa opisu archiwaliów $w$ zintegrowanych systemach informacji archiwalnej (seria Symposia archivistica, t. 1), red. R. Leśkiewicz, A. Żeglińska, Warszawa 2015; Komputeryzacja i digitalizacja $w$ archiwach (seria Symposia archivistica, t. 2), red. R. Leśkiewicz, A. Żeglińska, Warszawa 2016; Standaryzacja opisu archiwalnego (Symposia archivistica, t. 3), red. J. Bednarek, P. Perzyna, Warszawa-Łódź 2016.

10 Zob. Problemy archiwalnego opisu informacyjnego (seria Symposia archivistica, t. 4), red. W. Chorążyczewski, A. Rosa, Toruń-Warszawa 2017. 
Przedstawiony przegląd mojego metodologicznego i teoretycznego dorobku zwraca uwagę głównie na trzy wymienione książki poświęcone metodologii archiwistyki i problemom komputeryzacji archiwów. Pomijam kilkadziesiąt artykułów, które zawierają tylko komentarze do zasadniczych ustaleń. Pomijam także oczywiście mój dorobek z zakresu historii, bibliologii i informatyki historycznej.

\section{Bibliografia}

Bednarek, Jerzy, i Paweł Perzyna, red. Standaryzacja opisu archiwalnego. Symposia Archivistica 3. Warszawa; Łódź: Instytut Pamięci Narodowej. Komisja Ścigania Zbrodni przeciwko Narodowi Polskiemu, 2016.

Brenneke, Adolf. Archivkunde. Ein beitrag zur Theorie und Geschichte des europäischen Archivwesens. Wydał Wolfgang Leesch. Leipzig: Koehler \& Amelang, 1953.

Chorążyczewski, Waldemar. „Bohdan Ryszewski.” Archivní Časopis 62, nr 1 (2012): 40-45.

Chorążyczewski, Waldemar. „Profesor Bohdan Ryszewski - sylwetka uczonego.” Archeion 114 (2013): 13-21.

Chorążyczewski, Waldemar, i Agnieszka Rosa. „Szkoła naukowa Bohdana Ryszewskiego.” W Z uczniami, kolegami i przyjaciótmi w świecie nauki: prace dedykowane Profesorowi Bohdanowi Ryszewskiemu w osiemdziesiąta rocznicę urodzin, zredagowali Waldemar Chorążyczewski i Anna Żeglińska, 19-51. Olsztyn: Uniwersytet Warmińsko-Mazurski; Warszawa: Naczelna Dyrekcja Archiwów Państwowych, 2014.

Chorążyczewski, Waldemar, i Agnieszka Rosa, red. Problemy archiwalnego opisu informacyjnego. Symposia Archivistica 4. Warszawa: Instytut Pamięci Narodowej. Komisja Ścigania Zbrodni przeciwko Narodowi Polskiemu, 2017.

Chorążyczewski, Waldemar, i Anna Żeglińska, red. Z uczniami, kolegami i przyjaciótmi $w$ świecie nauki: prace dedykowane Profesorowi Bohdanowi Ryszewskiemu w osiemdziesiąta rocznicę urodzin. Olsztyn: Uniwersytet Warmińsko-Mazurski; Warszawa: Naczelna Dyrekcja Archiwów Państwowych, 2014.

Chorążyczewski, Waldemar, i Krzysztof Syta. „Profesor Bohdan Ryszewski: w 70. rocznicę urodzin." Archiwista Polski 9, nr 3 (2004): 9-16.

Gołembiowski, Maciej, oprac. „Bibliografia prac prof. dra hab. Bohdana Ryszewskiego.” W Archiwistyka i bibliotekoznawstwo: prace dedykowane Profesorowi Bohdanowi Ryszewskiemu, 13-19. Warszawa: Naczelna Dyrekcja Archiwów Państwowych, 1997.

Gołembiowski, Maciej, oprac. „Wykaz prac doktorskich i magisterskich napisanych pod kierunkiem prof. dra hab. Bohdana Ryszewskiego." W Archiwistyka i bibliotekoznawstwo: prace dedykowane Profesorowi Bohdanowi Ryszewskiemu, 20-29. Warszawa: Naczelna Dyrekcja Archiwów Państwowych, 1997.

Jaroszewicz-Pieresławcew, Zoja. „Profesor Bohdan Ryszewski - dyrektor Instytutu Historii i Stosunków Międzynarodowych Uniwersytetu Warmińsko-Mazurskiego w Olsztynie." W Historia, archiwistyka, informacja naukowa: prace dedykowane Profesorowi Bohdanowi Ryszewskiemu, zredagowała Marzena Świgoń, 31-33. Olsztyn: Wydawnictwo Uniwersytetu Warmińsko-Mazurskiego, 2009. 
Kopiczyńska, Alina. „Sylwetka Profesora Bohdana Ryszewskiego.” W Archiwistyka i bibliotekoznawstwo: prace dedykowane Profesorowi Bohdanowi Ryszewskiemu, 9-12. Warszawa: Naczelna Dyrekcja Archiwów Państwowych, 1997.

Leśkiewicz, Rafał, i Anna Żeglińska, red. Zasada strukturalna jako podstawa opisu archiwaliów $w$ zintegrowanych systemach informacji archiwalnej. Symposia Archivistica 1. Warszawa: Instytut Pamięci Narodowej. Komisja Ścigania Zbrodni przeciwko Narodowi Polskiemu, 2015.

Leśkiewicz, Rafał, i Anna Żeglińska, red. Komputeryzacja i digitalizacja $w$ archiwach. Symposia Archivistica 2. Warszawa: Instytut Pamięci Narodowej. Komisja Ścigania Zbrodni przeciwko Narodowi Polskiemu, 2016.

Majka, Roman. „Wkład Profesora Bohdana Ryszewskiego w komputeryzację Archiwum Generalnego Zgromadzenia Świętego Michała Archanioła." W Historia, archiwistyka, informacja naukowa: prace dedykowane Profesorowi Bohdanowi Ryszewskiemu, zredagowała Marzena Świgoń, 35-38. Olsztyn: Wydawnictwo Uniwersytetu Warmińsko-Mazurskiego, 2009.

Muller, Samuel, Johan A Feith, i Robert Fruin. Handleiding voor het ordenen en beschrijven van archieven: ontworpen in opdracht van de Vereeniging van Archivarissen in Nederland. Groningen: Erven B. van der Kamp, 1898.

Robótka, Halina, Bohdan Ryszewski, i Andrzej Tomczak. Archiwistyka. Warszawa: Państwowe Wydawnictwo Naukowe, 1989.

Ryszewski, Bohdan. Archiwistyka: przedmiot, zakres, podziat: (studia nad problemem). Roczniki Towarzystwa Naukowego w Toruniu 76, z. 2. Warszawa; Poznań: Państwowe Wydawnictwo Naukowe, 1972.

Ryszewski, Bohdan. Problemy i metody badawcze archiwistyki. Rozprawy / Uniwersytet Mikołaja Kopernika. Toruń: Uniwersytet Mikołaja Kopernika, 1985.

Ryszewski, Bohdan. Problemy komputeryzacji archiwów. Rozprawy / Uniwersytet Mikołaja Kopernika. Toruń: Wydawnictwo UMK, 1994.

Ryszewski, Bohdan. „Teoretyczne podstawy działalności archiwów.” W Archiwa w nowoczesnym społeczeństwie: pamiętnik V Powszechnego Zjazdu Archiwistów Polskich, Olsztyn 6-8 września 2007 r., zredagowali Jarosław Porazinski, Krzysztof Stryjkowski: 15-22. Warszawa: Stowarzyszenie Archiwistów Polskich, 2008.

Świgoń, Marzena. „Profesor Bohdan Stanisław Ryszewski - o życiu, pracy i promowaniu prac doktorskich." W Historia, archiwistyka, informacja naukowa: prace dedykowane Profesorowi Bohdanowi Ryszewskiemu, zredagowała Marzena Świgoń, 13-20. Olsztyn: Wydawnictwo Uniwersytetu Warmińsko-Mazurskiego, 2009.

Żeglińska, Anna. „Profesor Bohdan Ryszewski - jubileuszowe refleksje uczniów o Mistrzu." W Historia, archiwistyka, informacja naukowa: prace dedykowane Profesorowi Bohdanowi Ryszewskiemu, zredagowała Marzena Świgoń, 21-24. Olsztyn: Wydawnictwo Uniwersytetu Warmińsko-Mazurskiego, 2009.

Żeglińska, Anna, oprac. „Wykaz prac magisterskich napisanych pod kierunkiem prof. dr. hab. Bohdana Ryszewskiego, prof. zw." W Historia, archiwistyka, informacja naukowa: prace dedykowane Profesorowi Bohdanowi Ryszewskiemu, zredagowała Marzen Świgoń, 25-29. Olsztyn: Wydawnictwo Uniwersytetu Warmińsko-Mazurskiego, 2009. 
